\title{
First record of the genus Hyalella (Amphipoda: Hyalellidae) from Santa Catarina State, Brazil, with description of two new species
}

\author{
Giovanna O. Reis ${ }^{1} \mathbb{D}$, Ludmila R. Penoni $^{2}$ \& Alessandra A. P. Bueno ${ }^{2}$ \\ ${ }^{1}$ Universidade Federal de Lavras, Departamento de Biologia, Setor de Ecologia, Laboratório de Carcinologia, \\ Campus Universitário, Centro, CEP 37200-900, Lavras, MG, Brasil \\ ${ }^{2}$ Universidade Federal de Lavras, Departamento de Biologia, Programa de Pós-Graduação em Ecologia \\ Aplicada. Campus Universitário, Lavras, CEP 37200-900, MG, Brasil \\ Corresponding author: Giovanna O.Reis,e-mail: gideoliveirareis@gmail.com
}

REIS, G.O., PENONI, L.R., BUENO, A.A.P. First record of the genus Hyalella (Amphipoda: Hyalellidae) from Santa Catarina State, Brazil, with description of two new species. Biota Neotropica 20(2): e20190879. https://doi.org/10.1590/1676-0611-BN-2019-0879

\begin{abstract}
The amphipod Hyalella Smith, 1874 is exclusive to the Americas, and the South region of Brazil presents the greatest diversity of the genus. This paper presents two species of Hyalella from Santa Catarina state, Brazil. A new species from the municipality of Palmeira is characterized by oval eyes, absence of flanges, epimeral plates not accuminated, presence of three lateral pappose setae on article 4 in antenna 2, absence of plumose setae in the maxilliped, presence of comb-scales and absence of serrate setae in the gnathopods, presence of curved seta on the inner ramus of the uropod 1 and absence of lateral setae on the telson. A new species from Rio das Antas municipality main characteristics are absence of flanges, epimeral plates accuminated, absence of plumose setae and distal nail in the maxilliped, presence of comb-scales and absence of serrate setae in gnathopods, presence of curved seta on the inner ramus of the uropod 1 and absence of lateral setae on the telson. Here we expand the distribution and increase the morphological and taxonomic knowledge of the genus.
\end{abstract}

Keywords: Crustacea, freshwater, systematic, taxonomy.

\section{Primeiro registro do gênero Hyalella (Amphipoda: Hyalellidae) para o estado de Santa Catarina, Brasil, com descrição de duas novas espécies}

Resumo: O gênero de anfípodes Hyalella Smith, 1874 é exclusivo das Américas, e a região Sul do Brasil apresenta a maior diversidade do gênero. Este artigo apresenta duas novas espécies de Hyalella para o estado de Santa Catarina, Brasil. Uma nova espécie do município de Palmeira é caracterizada por olhos ovais, ausência de flanges, placas epimerais não acuminadas, presença de três setas paposas laterais no artigo 4 na antena 2, ausência de setas plumosas no maxilípodo, presença de comb scales e ausência de setas serradas nos gnatópodos, presença de seta curva no ramo interno do urópodo 1 e ausência de setas laterais no télson. Uma nova espécie do município de Rio das Antas tem como principais características ausência de flanges, placas epimerais acuminadas, ausência de setas plumosas e unha distal no maxilípodo, presença de comb scales e ausência de setas serradas nos gnatópodos, presença de seta curva no ramo interno do urópodo 1 e ausência de setas laterais no télson. Aqui expandimos a distribuição e aumentamos o conhecimento morfológico e taxonômico do gênero.

Palavras-chave: Crustacea, dulcícola, sistemática, taxonomia. 


\section{Introduction}

The genus Hyalella Smith, 1874 consists of species restricted to the Nearctic and Neotropical biogeographical regions, and it occurs from Patagonia to the southern region of Canada (Bueno et al. 2014). Populations of the genus are found in a great variety of habitats, such as flooded areas, in association with aquatic vegetation, lakes, ponds and in underground aquatic environments (Grosso \& Peralta 1999; Rodrigues et al. 2017).

South America bears almost $80 \%$ of the diversity of the genus (Rodrigues et al. 2014; Colla \& César 2015; Streck et al. 2017; BastosPereira et al. 2018; Streck-Marx \& Castiglioni 2019), yet only less than a third of the ecological studies with the genus deals with its southern species. There are 76 species described (Bueno et al. 2019; Streck-Marx \& Castiglioni 2019), 28 of which are from Brazil (Rodrigues et al. 2014; Streck et al. 2017; Bastos-Pereira et al. 2018; Peralta \& Isa Miranda 2019; Streck-Marx \& Castiglioni 2019). The Southern Brazilian region presents the greatest diversity of the genus Hyalella.

There are 12 known species occurring in Rio Grande do Sul (Streck-Marx \& Castiglioni 2019): H. curvispina Shoemaker, 1942; H. pampena Cavalieri, 1968; H. montenegrinae Bond-Buckup \& Araujo, 1998; H. pseudoazteca González \& Watling, 2003; H. castroi González, Bond-Buckup \& Araujo, 2006; H. pleoacuta González, Bond-Buckup \& Araujo, 2006; H. bonariensis Bond-Buckup, Araujo \& Santos, 2008; H. imbya Rodrigues \& Bueno, 2012; H. kaingang Araujo \& Cardoso, 2013; H. gauchensis Streck \& Castiglioni, 2017; H. georginae Streck \& Castiglioni, 2017; and H. palmeirensis Streck-Marx \& Castiglioni, 2019. For Paraná state, there are only two records for the genus: H. brasiliensis Bousfield, 1996; H. formosa Cardoso \& Araujo, 2014 (Cardoso et al. 2014; Streck et al. 2017). Geographically close, but found in Argentina, there is also H. misionensis Colla \& Cesar, 2015; this species is included in the taxonomical remarks and discussion sections.
This paper aims to extend the distribution of the genus Hyalella in the Southern Brazil, with the description of two new species from the central region of Santa Catarina State.

\section{Material and Methods}

The specimens were collected in different localities of Santa Catarina state, both belonging to the Uruguay Basin; one in a flooded area of Ribeirão Antônio (27³5'28.2'S 507'54.4”'W; $~ 880 \mathrm{~m}$ of altitude) in the municipality of Palmeira, central portion of the state; and another in a private lake, on road SC135, municipality of Rio das Antas (26 $57^{\circ} 1.9^{\prime \prime} \mathrm{S} 51^{\circ} 6$ ' $47.5^{\prime \prime} \mathrm{W}$; $772 \mathrm{~m}$ of altitude), northern in relation to the other (Figure 1).

The material was collected using a hand net and preserved in $70 \%$ ethanol. The head length was obtained from the insertion of the antennas until the beginning of the first thoracic segment, the body length was measured from the head to the last segment, except for the telson.

Random animals from both locations were selected to be dissected and mounted on slides. First, they were colored for $24 \mathrm{~h}$ using the "red congo" dye to increase color contrast. After that, the dissection was performed under a Carl Zeiss Stemi 508 stereoscope, using glycerin as a dissection medium with the aid of fine needles. The dissected appendages were put on slides containing natural Canada balsam as medium and covered by cover slip. We used varnish to seal the slides. The photos used as base for the illustrations were produced with a Carl Zeiss Primo Star microscope, with an Carl Zeiss AxioCam ERc5s camera coupled. The illustrations were made using the CorelDraw X7 software. The description of cuticular structures followed terminology by Zimmer et al. (2009). The type material was deposited in Museu de Zoologia da Universidade de São Paulo (MZUSP) and in Coleção de Crustáceos da Universidade Federal de Lavras (CCUFLA).

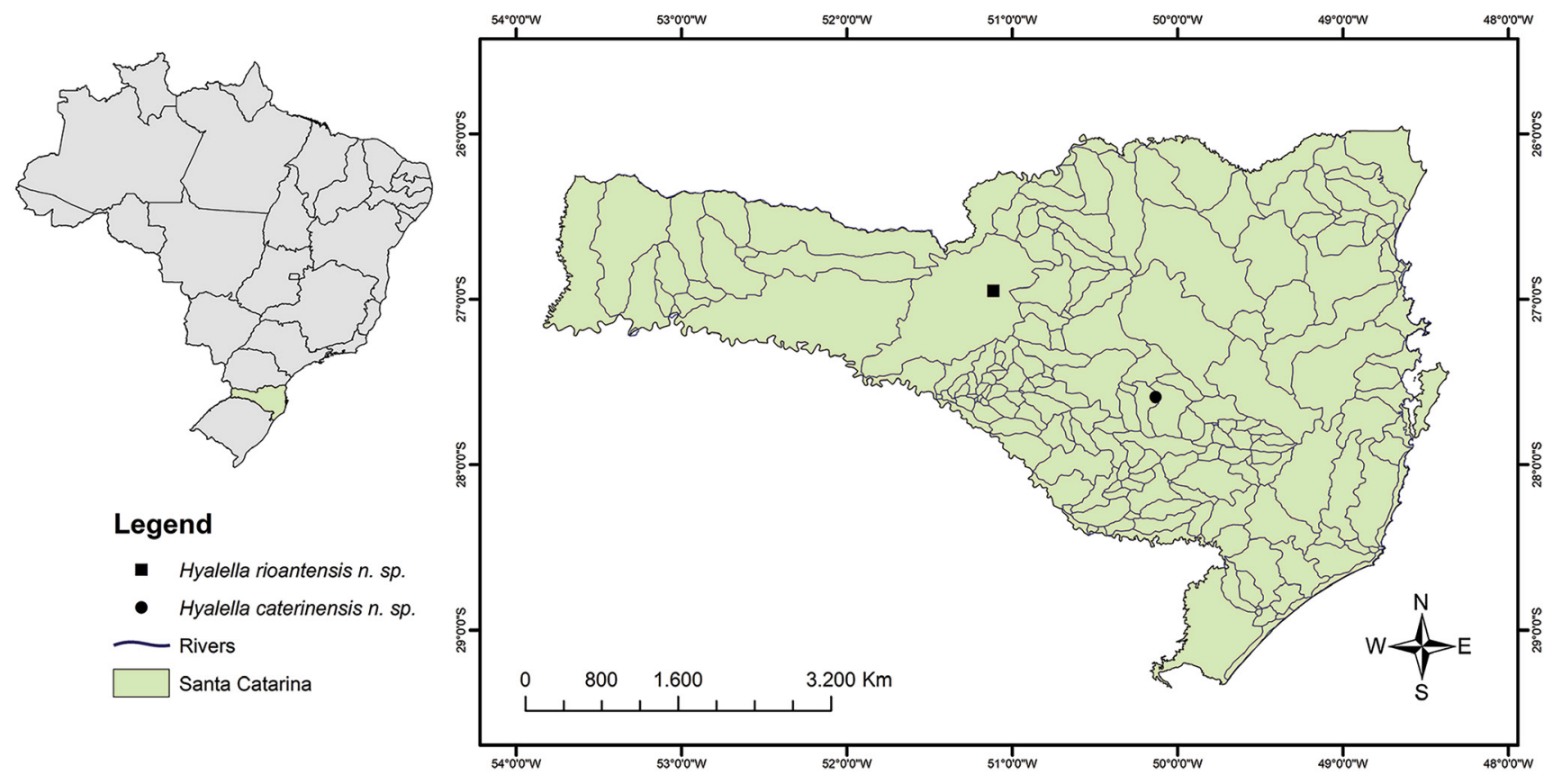

Figure 1. Map showing collection sites in Santa Catarina State. 


\section{Results}

\section{Taxonomy}

Order Amphipoda Latreille, 1816

Suborder Senticaudata Lowry \& Myers, 2013

Family Hyalellidae Bulycheva, 1957

Genus Hyalella S. I. Smith, 1874

\section{Hyalella catarinensis n. sp. Reis \& Bueno}

(Figures 2-7)

Type material. Holotype male, body length $=7.88 \mathrm{~mm}$, head length $=0.68 \mathrm{~mm}$, Alagado do Ribeirão Antônio, municipality of Palmeira, Santa Catarina state, Brazil, (27³5'28.2”S 507'54.4”W) MZUSP 39529, December/2012, G. Bond-Buckup, C. Sokolowicz coll. Paratype female, body length $=6.76 \mathrm{~mm}$, head length $=0.60 \mathrm{~mm}$, MZUSP 39530; twenty whole individuals and two male and one female in slides CCUFLA 405 (same collection data of the holotype).

Diagnosis. (Figures 2-7) Smooth body surface. Epimeral plates not accuminated. Antenna 2 article 4 with three lateral pappose setae. Maxilla 1, Maxilla 2 and Mandibles with presence of papposerrate setae. Maxilliped without comb-scales and plumose setae. Gnathopod 2 with presence of comb-scales, without serrate setae, palm longer than posterior margin of propodus. Inner ramus on uropod 1 of male with two dorsal cuspidate setae, with accessory seta; one curved seta followed by four cuspidate setae apically, only one with accessory seta. Telson $1.7 x$ longer than wide, apically rounded with three apical cuspidate

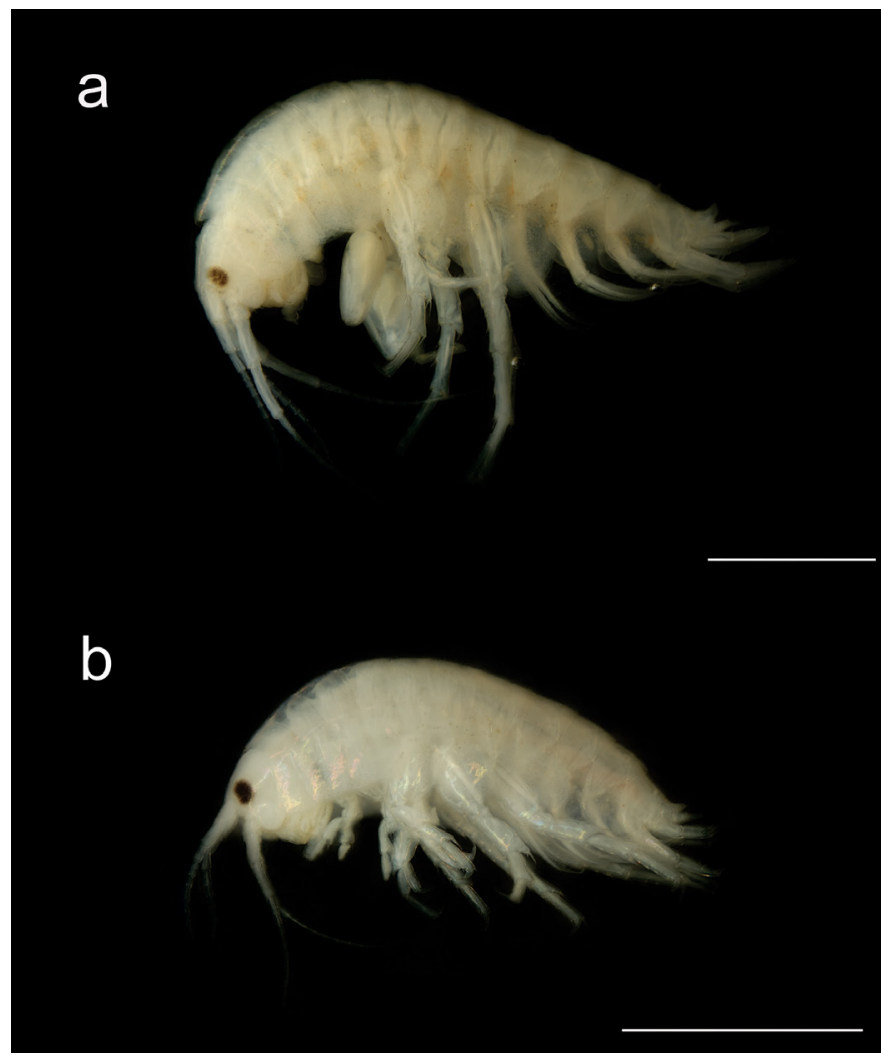

Figure 2. Hyalella catarinensis n. sp., municipality of Palmeira, Santa Catarina State, Brazil (2735'28.2"S 507'54.4”W). Holotype, male, 7.88 mm, MZUSP 39529 (a). Paratype, female, $5.25 \mathrm{~mm}$, MZUSP 39530 (b). Scale bars $=2 \mathrm{~mm}$.

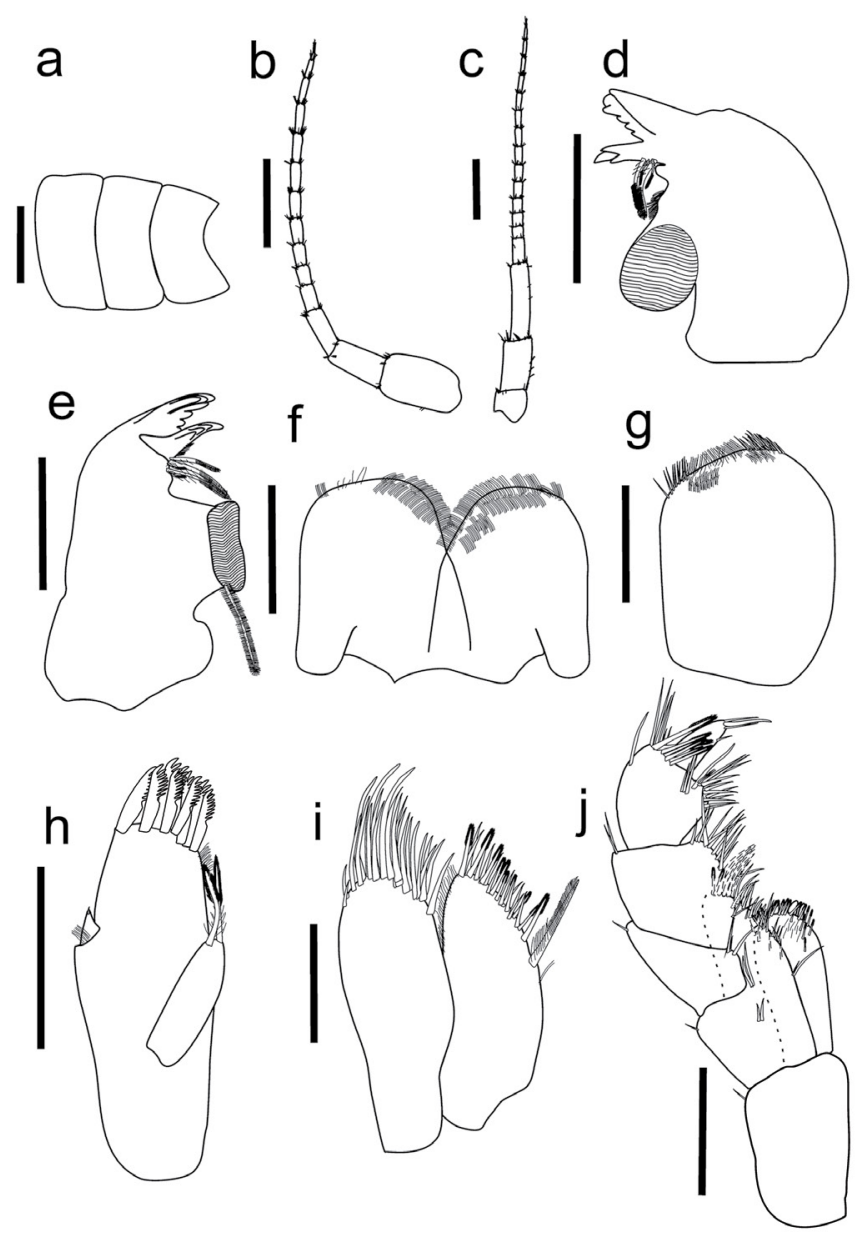

Figure 3. Hyalella catarinensis n. sp., municipality of Palmeira, Santa Catarina State, Brazil $\left(27^{\circ} 35^{\prime} 28.2^{\prime \prime}\right.$ S 507'54.4”W). Paratype, male, $7.60 \mathrm{~mm}$. Epimeral plates not accuminated (a). Antenna 1 (b). Antenna 2 (c). Right mandible (d). Left mandible (e). Lower lip (f). Upper lip (g). Maxilla 1 (h). Maxilla 2 (i). Maxilliped (j). Scale bars: $a=2 \mathrm{~mm}$; $b$ and $c=500 \mu \mathrm{m}$; $d$ to $j=200 \mu \mathrm{m}$.

setae, with accessory seta. Coxal gills sac-like present on segments 2 to 6. Sternal gills present on segments 2 to 7 .

Description of male. Mean body length: $5.40 \pm 0.72 \mathrm{~mm}(N=10)$, minimum body length $=4.44 \mathrm{~mm}$, maximum body length $=7.88 \mathrm{~mm}$; mean head length: $0.57 \mathrm{~mm} \pm 0.07 \mathrm{~mm}(N=10)$, minimum head length $=0.48 \mathrm{~mm}$, maximum head length $=0.70 \mathrm{~mm}$. Body surface smooth. Epimeral plates not accuminated (Figure 3a). Coxae 1-4 subequal in size and shape, slightly overlapping. Coxa 1 similar to 2 and 3 . Coxa 3 wider than 4 . Coxa 4 longer than wide, excavated posteriorly. Coxa 5 posterior lobe narrower than anterior lobe. Coxa 6 anterior lobe small. Coxa 7 reduced. Head 1.26x smaller than first two thoracic segments. Eyes oval and pigmented.

Antenna 1 (Figure 3b) 3.2x smaller than body length, 1.3x smaller than antenna 2, 2x longer than peduncle of antenna 2; peduncle 2.6x longer than head; article 1 longer than 2 , article 3 shorter than 1 and 2; flagellum with 14 articles, $4.3 \mathrm{x}$ longer than peduncle; aesthetascs occurring distally on flagellum from article 7 to 12 .

Antenna 2 (Figure 3c) 2.5x smaller than body length, peduncle slender, $3.4 \mathrm{x}$ longer than wide, $1.7 \mathrm{x}$ longer than head; article 4 shorter 


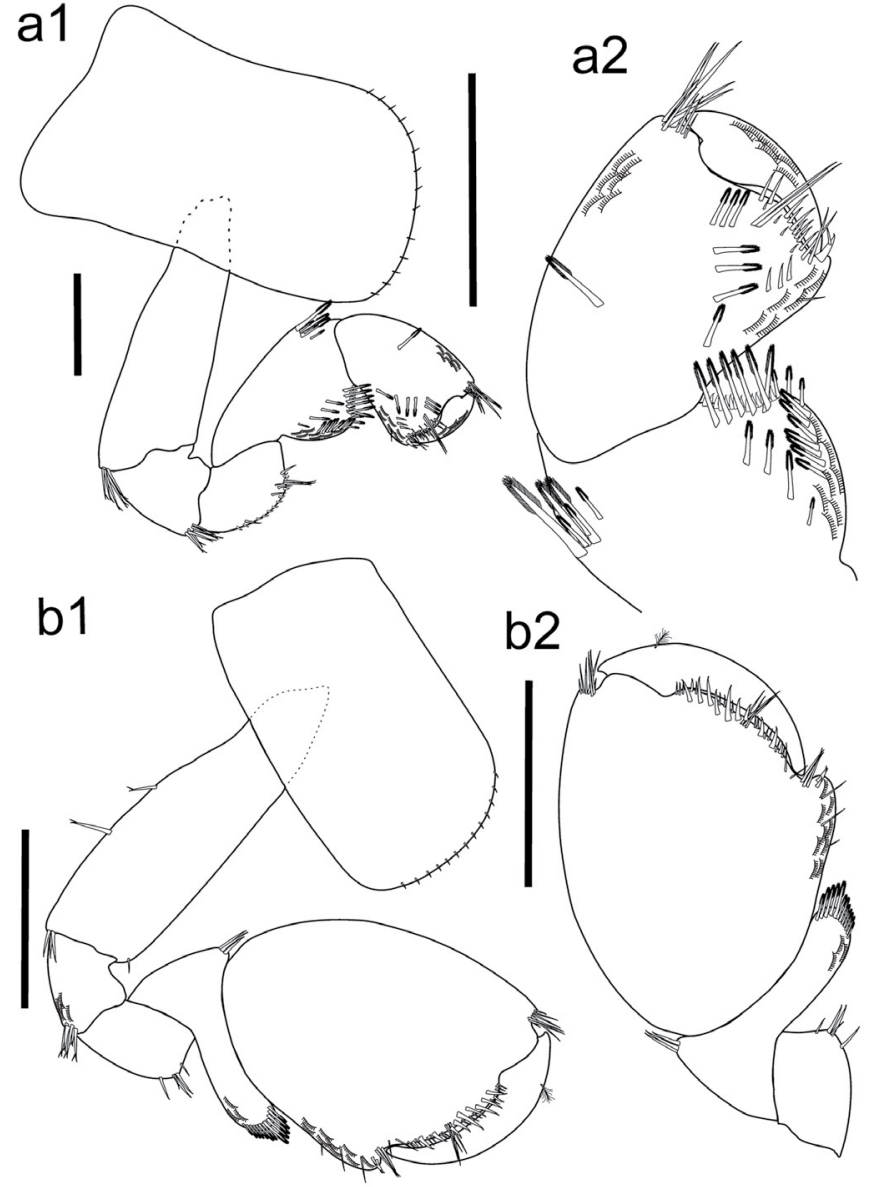

Figure 4. Hyalella catarinensis n. sp., municipality of Palmeira, Santa Catarina State, Brazil (27³5'28.2” S 507'54.4”W). Paratype, male, $7.60 \mathrm{~mm}$. Gnathopod 1 (a1). Detail of the carpus, propodus and dactylus (a2). Gnathopod 2 (b1). Detail of the merus, carpus, propodus and dactylus (b2). Scale bars $=500 \mu \mathrm{m}$.

than article 5, with three lateral pappose setae; flagellum with 14 articles, $1.5 \mathrm{x}$ longer than peduncle;

Mandible without palp; incisor toothed; left (Figure 3e) lacinia mobilis with four teeth and setal row with five papposerrate setae, molar process with accessory seta; right mandible (Figure $3 \mathrm{~d}$ ) with four papposerrate setae; molar process broad and cylindrical.

Upper lip (Figure 3g) margin rounded; distal border covered by setules and simple setae on distal ventral and dorsal faces. Lower lip (Figure 3f) outer lobes rounded with apical setules.

Maxilla 1 (Figure 3h) inner plate slender, 2.7x shorter than outer plate, with two long apical papposerrate setae. Outer plate with seven to nine serrate setae. Palp short, uniarticulate, longer than wide, reaching more than half of the distance between the base of the palp and base of setae on outer plate, with a distal short seta and setules.

Maxilla 2 (Figure 3i) inner plate slightly shorter than outer plate, inner plate with one papposerrate seta, ten pappose setae, several simple setae; outer plate with several simple distal setae; inner and outer plates covered by several setules.

Maxilliped (Figure 3j) inner plate 6.3x longer than wide, with several pappose and three cuspidate apical setae; outer plate $6.3 \mathrm{x}$ smaller than inner plate, with three pappose and several simple setae

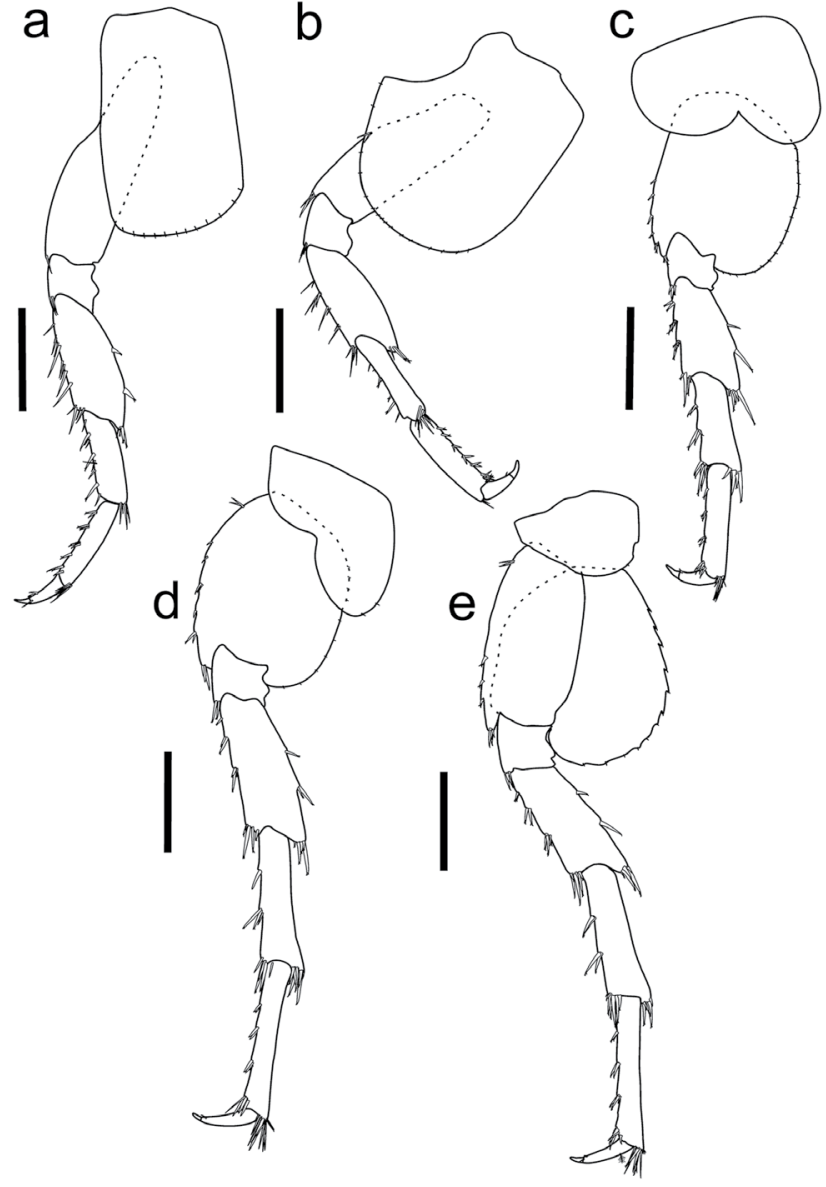

Figure 5. Hyalella catarinensis n. sp., municipality of Palmeira, Santa Catarina State, Brazil (27³5’28.2” S 507'54.4” W). Paratype, male, $7.60 \mathrm{~mm}$. Pereopod 3 (a). Pereopod 4 (b). Pereopod 5 (c). Pereopod 6 (d). Pereopod 7 (e). Scale bars: $500 \mu \mathrm{m}$.

on the margin; palp subequal to inner plate and $6 \mathrm{x}$ longer than outer plate, four articles; article $11.2 \mathrm{x}$ longer than wide, outer margin with a simple setae; article $21.1 \mathrm{x}$ wider than long, inner margin with several long simple setae; article $32.3 x$ longer than wide, inner margin with several long simple setae, outer margin with pappose and long simple setae; dactylus unguiform, $1.7 \mathrm{x}$ longer than third article, distal setae simple shorter than nail, distal nail present.

Gnathopod 1 (Figure 4a1, a2) subchelate; coxal plate 1.8x longer than wide, with simple setae on the margin; basis and ischium with simple setae dorsally with accessory setae; merus with simple setae with accessory setae, margin with denticles; carpus $1.6 \mathrm{x}$ wider than long, shorter than propodus, with lateral distal lobe produced and forming a scoop-like structure, with several pappose setae and comb-scales; propodus $1.3 \mathrm{x}$ longer than wide, hammer-shaped, with several simple long setae on disto-anterior margin, comb-scales present, inner margin with 4 pappose setae, with few simple setae and comb-scales on the disto-posterior margin; palm slope oblique, margin slightly concave, palm with many simple setae, posterior distal corner with one cuspidate setae with an accessory seta; dactylus claw-like, comb-scales present on distal margin. 


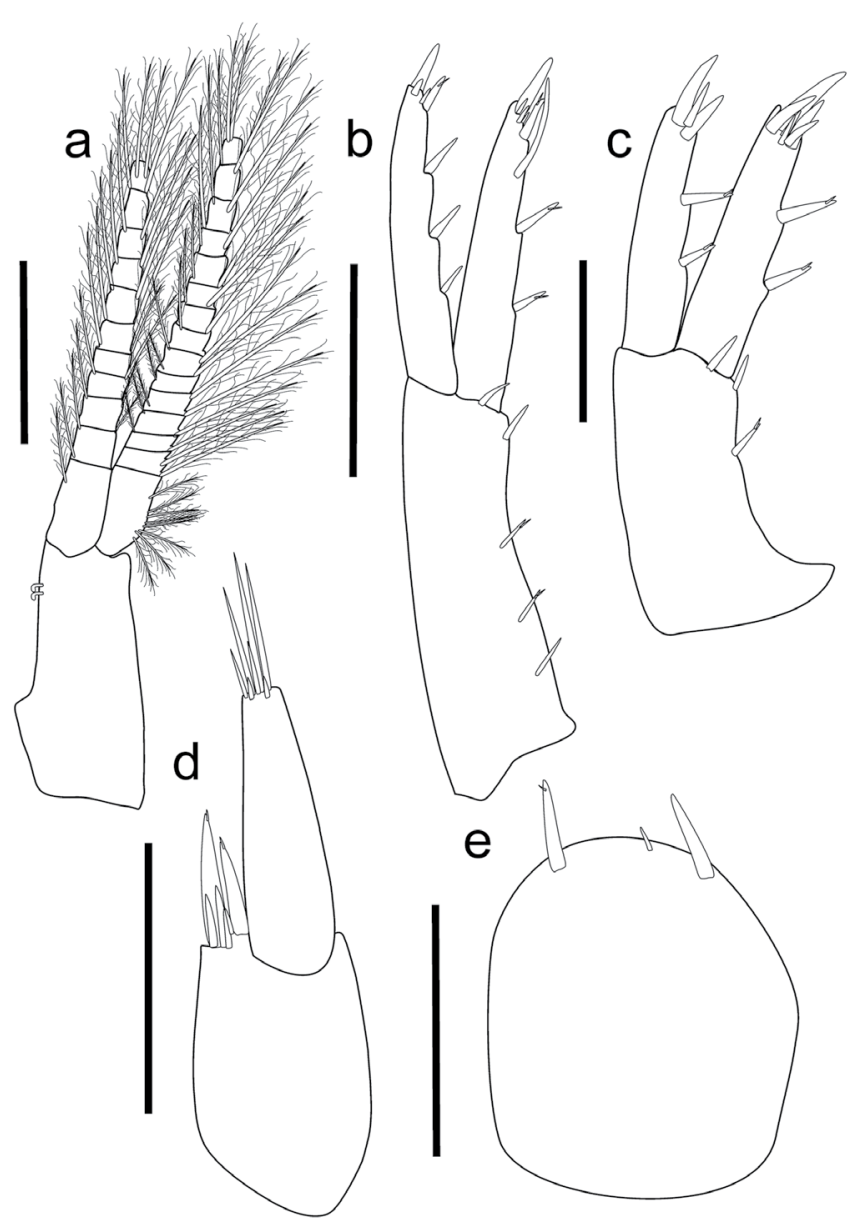

Figure 6. Hyalella catarinensis n. sp., municipality of Palmeira, Santa Catarina State, Brazil (2735'28.2” S 507'54.4” W). Paratype, male, $7.60 \mathrm{~mm}$. Pleopod (a). Uropod 1 (b). Uropod 2 (c). Uropod 3 (d). Telson (e). Scale bars: a,b,d and $\mathrm{e}=500 \mu \mathrm{m} ; \mathrm{c}=250 \mu \mathrm{m}$.

Gnathopod 2 (Figure 4b1, b2) subchelate; coxal plate 1.8x longer than wide, with simple setae on the margin; basis with several simple setae with accessory seta on posterior margin; merus with simple setae on posterior margin; carpus 1.6x wider than long, posterior lobe narrow produced between merus and propodus, margin with pappose and simple setae, with comb-scales; propodus ovate, $1.3 \mathrm{x}$ longer than wide, combscales present; palm longer than posterior margin of propodus, convex, with one row of several cuspidate setae and simple setae, posterior distal corner with two long and strong cuspidate setae, only one with accessory seta, and with a cup for dactylus; dactylus claw-like, congruent with palm, plumose seta dorsally, comb-scales absent.

Pereopods 3 to 7 (Figure 5a-e) simple. Pereopods 3 and 4 merus and carpus posterior margin with clusters of simple setae; propodus posterior margin of pereopods 3 and 4 with cuspidate setae with accessory seta; dactylus 1.9x shorter than propodus on Pereopods 3 and 1.9x on Pereopod 4. Pereopods 5 to 7 merus, carpus and propodus posterior margin with three-four marginal clusters of one-eight cuspidate setae with accessory seta, dactylus $2.4 \mathrm{x}$ shorter than propodus. Pereopod 3 and pereopod 4 similar sizes; pereopod 5 smaller than others; pereopod 6 larger than pereopod 7, which is similar in size to the pereopod 3.

Pleopods (Figure 6a) peduncle 1.6x shorter than rami, with two coupling spines; both rami with several plumose setae.

https://doi.org/10.1590/1676-0611-BN-2019-0879

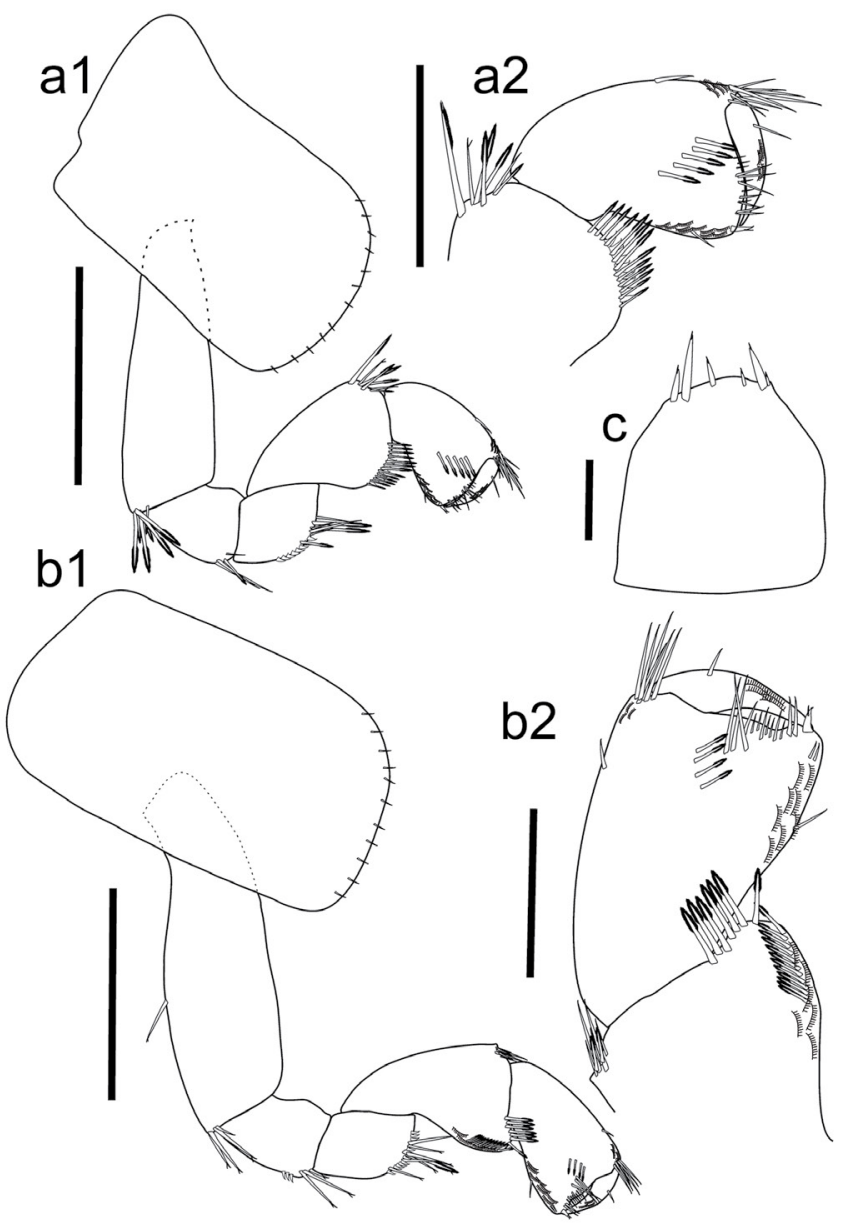

Figure 7. Hyalella catarinensis n. sp., municipality of Palmeira, Santa Catarina State, Brazil (2735'28.2” S 507'54.4” W). Paratype, female, $6.76 \mathrm{~mm}$. Gnathopod 1 (a1). Detail of the carpus, propodus and dactylus (a2). Gnathopod 2 (b1). Detail of the carpus, propodus and dactylus (b2). Telson (c). Scale bars: $\mathrm{a} 1$ and $\mathrm{b} 1=500 \mu \mathrm{m} ; \mathrm{a} 2$ and $\mathrm{b} 2=250 \mu \mathrm{m} ; \mathrm{c}=100 \mu \mathrm{m}$.

Uropod 1 (Figure 6b) 1.2x longer than uropod 2; peduncle 1.6x longer than outer ramus and 1.6x than inner ramus, with five cuspidate setae with accessory seta; rami subequal; inner ramus with two dorsal cuspidate setae with accessory seta on the margin, and curved seta followed by four cuspidate setae apically, only one with accessory seta; outer ramus with three dorsal cuspidate setae on the margin and four cuspidate setae apically, only one with accessory seta.

Uropod 2 (Figure 6c) 1.2x shorter than uropod 1, peduncle 2.7x longer than outer ramus and $2.4 \mathrm{x}$ than inner ramus, $2.2 \mathrm{x}$ wider than outer ramus and $1.8 \mathrm{x}$ than inner ramus, with three cuspidate setae, only one with an accessory seta; inner ramus with two dorsal cuspidate setae with an accessory seta and six cuspidate setae apically; outer ramus with two dorsal cuspidate setae with an accessory seta and three apical cuspidate setae.

Uropod 3 (Figure 6d) 1.8x shorter than peduncle of uropod 1 and $1.4 \mathrm{x}$ than peduncle of uropod 2 ; peduncle $1.7 \mathrm{x}$ longer than wide, with six cuspidate setae, only two with accessory seta; inner ramus absent; outer ramus uniarticulate, subequal in length to peduncle; basal width $1.8 \mathrm{x}$ more than apex of ramus, with seven simple setae apically. 
Telson (Figure 6e) entire, 1.7x longer than wide, apically rounded, with three apical cuspidate setae with accessory seta, without setae laterally.

Coxal gills sac-like, present on pereonites 2 to 6 . Sternal gills tubular present on pereonites 2 to 7 .

Female (Figure 2b). Mean body length: $4.96 \pm 0.61 \mathrm{~mm}(N=10)$, minimum body length $=3.72 \mathrm{~mm}$, maximum body length $=6.76 \mathrm{~mm}$; mean head length: $0.52 \pm 0.07 \mathrm{~mm}(N=10)$, minimum head length $=$ $0.36 \mathrm{~mm}$, maximum head length $=0.67 \mathrm{~mm}$. Gnathopod 1 (Figure $7 \mathrm{a} 1$, a2) similar to male gnathopod 1 ; carpus $1.3 x$ longer than wide, without comb-scales; with posterior lobe produced and forming a scoop-like structure, with pectinate margin, with several pappose setae; propodus $2.4 \mathrm{x}$ longer than wide, hammer-shaped, palm $3.6 \mathrm{x}$ shorter than posterior margin of propodus, with comb-scales, inner margin with few simple setae with accessory seta, palm slope transverse with comb-scales, dactylus claw-like, with comb-scales. Gnathopod 2 (Figure 7b1, b2) similar in size and shape to gnathopod 1; different in shape to male gnathopod 2 and smaller; propodus 1.6x as long as wide, subchelate, inner margin with few simple setae, palm oblique with several long simple setae, with comb-scales. Uropod 1 similar in size and shape to male uropod 1, except for the absence of curved seta. Telson (Figure 7c) similar in shape to male, with six cuspidate setae with accessory seta.

Taxonomical remarks. Among all species that occur in southern Brazil, Hyalella catarinensis n. sp. shares the presence of curved seta in the inner ramus of uropod 1 with $H$. bonariensis, H. brasiliensis, $H$. castroi, H. curvispina, H. gauchensis, H. georginae, H. kaingang, $H$. misionensis, $H$. montenegrinae, $H$. palmeirensis, $H$. pampeana and $H$. pleoacuta. In this group, the new species differs from $H$. pleoacuta and $H$. kaingang by the absence of flanges and from $H$. pleoacuta, $H$. kaingang and $H$. palmeirensis by the epimeral plates not accuminate. The absence of plumose setae in maxilla 2 distinguishes the new species from $H$. curvispina, $H$. montenegrinae, $H$. pampeana and $H$. brasiliensis. By the absence of plumose setae in the maxilliped it is possible to differentiate $H$. catarinensis n. sp. from $H$. montenegrinae, $H$. castroi and H. pleoacuta. Hyalella catarinensis n. sp. does not resemble $H$. brasiliensis, $H$. georginae and $H$. palmeirensis due to the propodus of gnathopod 2 having a palm longer than posterior margin. The characteristic that makes it possible to differentiate the new species from a large group of species including $H$. pampeana, H. montenegrinae, $H$. bonariensis, $H$. kaingang, $H$. georginae, $H$. gauchensis and $H$. palmeirensis is the absence of lateral setae in the telson. The presence of three lateral pappose seta in antenna 2 article 4 is a unique feature not found in any of the previously described species. All similarities and differences between $H$. catarinensis $\mathrm{n}$. sp. and others species can be checked on Table 1 .

Etymology: The species epithet "catarinensis" is in reference to the state of Santa Catarina and a reference of the first record of the genus for the state.

Habitat and Ecological Conservation: Epigean. Place of collection of the specimens without traces of pollution, however, with maize plantations in the surroundings.

\section{Hyalella rioantensis n. sp. Penoni \& Bueno}

(Figures 8-13)

Type material. Holotype male, body length $=8.03 \mathrm{~mm}$, head length $=1.05 \mathrm{~mm}$, private lake in road SC 135, municipality of Rio das Antas, state of Santa Catarina, Brazil, (2657'1.9”S 516'47.5”W),
MZUSP 39531, May/2005, Bond-Buckup coll. Paratypes female, body length $=6.44 \mathrm{~mm}$, head length $=1.12 \mathrm{~mm}$, MZUSP 39532; 110 whole individuals and 17 male and 10 female in slides CCUFLA 88 (same collection data of the holotype).

Diagnosis. (Figures 8-13) Body surface smooth. Epimeral plates accuminated. Eyes round, pigmented. Antenna $10.8 \mathrm{x}$ shorter than antenna 2. Antenna 2 about half body length. Maxilla 1 palp longer than wide, more than half the distance between base of palp and base of setae on outer plate; inner plate slender, with two papposerrate apical setae. Maxilla 2 inner plate with 23 papposerrate and several simple setae on inner margin. Gnathopod 1 propodus 1.6x longer than wide, hammer-shaped, inner face with two rows of simple seta and cuspidate seta, anterior and posterior margins with comb-scales. Gnathopod 2 ovate, palm equal in size to posterior margin of propodus, slope oblique. Uropod 1 of male with curved seta on inner ramus. Uropod 3 peduncle wider and shorter than ramus, with five distal setae with accessory seta and a dorsal simple seta. Telson slightly longer than wide, apically rounded, with four apical cuspidate setae with accessory seta. Coxal gills sac-like and sternal gills present on segments 2 to 7 .

Description of male. Mean body length: $6.24 \pm 1.02 \mathrm{~mm}(N=$ 10), minimum body length $=6.09 \mathrm{~mm}$, maximum body length $=8.03$ $\mathrm{mm}$; mean head length: $0.74 \mathrm{~mm} \pm 0.12 \mathrm{~mm}(N=10)$, minimum head length $=1.05 \mathrm{~mm}$, maximum head length $=0.84 \mathrm{~mm}$. Body surface smooth. Epimeral plates accuminated (Figure 9a). Coxae 1-4 slightly overlapping. Coxa 1 similar to 2 and 3. Coxa 3 narrower than 4. Coxa 4 deeper than wide, excavated posteriorly. Coxa 5 wider than longer. Coxa 6 longer than wide. Coxa 7 reduced. Head smaller than first two thoracic segments. Eyes round and pigmented.

Antenna 1 (Figure $9 b$ ) about $0.83 x$ half body length, $0.8 x$ the total length of antenna 2, 1.8x longer than peduncle of antenna 2 ; peduncle $1.3 x$ longer than head; article $11.4 x$ longer than 2 , article $30.6 x$ shorter than 1 and $0.8 \mathrm{x}$ shorter than article 2; flagellum with 11 to 14 articles, $1.5 \mathrm{x}$ longer than peduncle; aesthetascs occurring on flagellum from article 5 distally.

Antenna 2 (Figure 9c) 0.9x the length of half the body; peduncle slender, $1.8 \mathrm{x}$ longer than head, article $40.8 \mathrm{x}$ shorter than article 5, flagellum with 14 to 18 articles, $1.1 x$ longer than peduncle.

Mandible without palp; incisor toothed; left (Figure 9e) lacinia mobilis with four teeth and setal row with five papposerrate setae; right mandible (Figure 9d) with four papposerrate setae; molar process broad and cylindrical with accessory seta.

Upper lip (Figure 9g) margin rounded; distal border covered by setules on ventral and dorsal faces. Lower lip (Figure 9f) outer lobes rounded and distally notched, with setules on dorsal and ventral faces.

Maxilla 1 (Figure 9h) inner plate slender, shorter than outer plate, with two apical papposerrate setae and setules on the margins. Outer plate with nine serrate setae. Palp short, uniarticulate, longer than wide, reaching more than half of the distance between the base of the palp and base of setae on outer plate, with distal setules.

Maxilla 2 (Figure 9i) inner plate subequal to outer plate, inner plate with several papposerrate setae and few simple setae; outer plate with a pappose setae and several simple setae; inner and outer plates covered by setules.

Maxilliped (Figure 9j1, j2) inner plate longer than wide, with three cuspidate distal setae and several apical and medial pappose setae, without comb-scales; outer plate subequal to inner plate, with several 


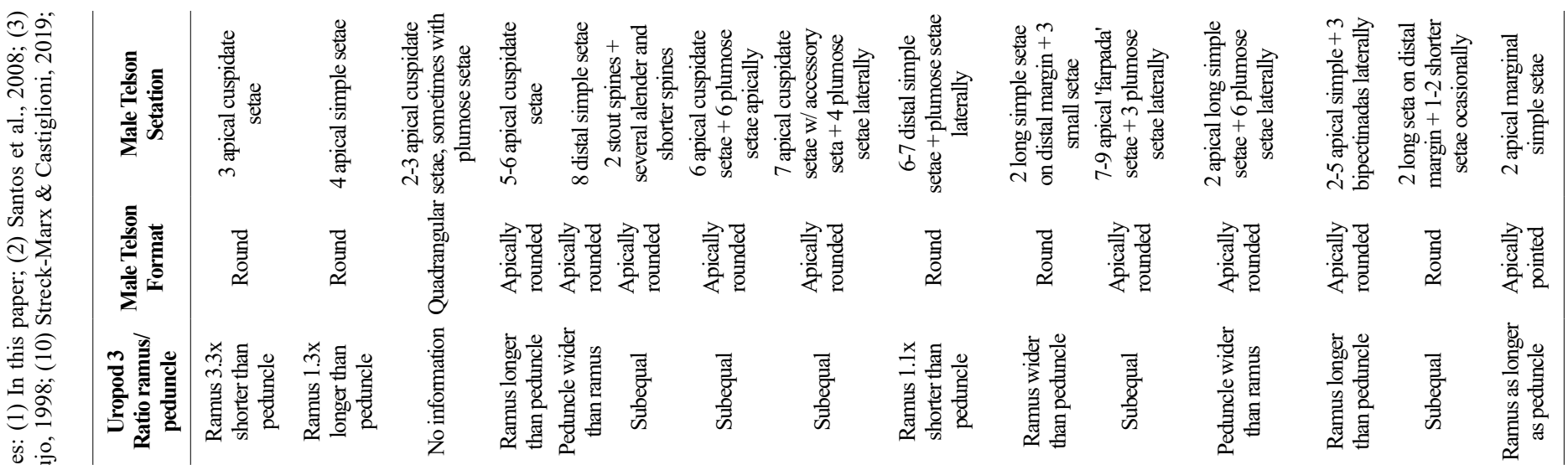

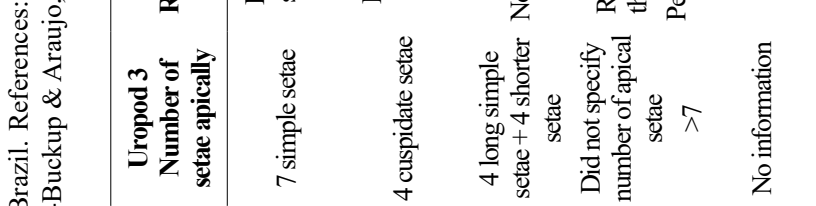

1 InUnUy?

留

s.․․․

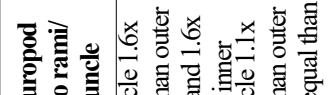

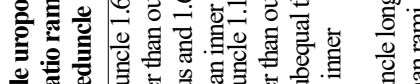

In-1)

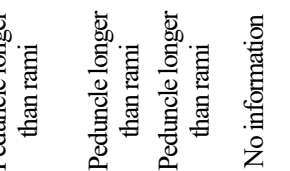

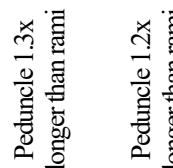

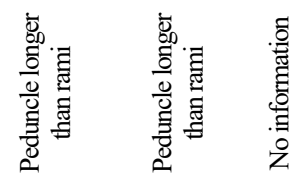

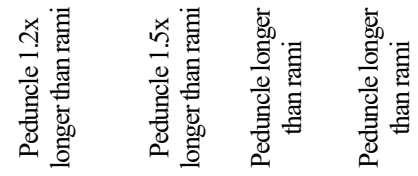

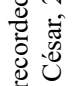

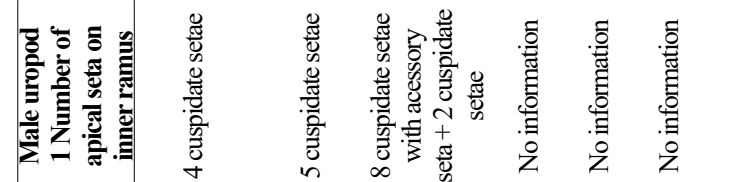

咅

章量意

:

(1)

ต흘

(1)

In

政

茫

㱐

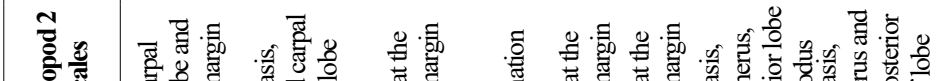

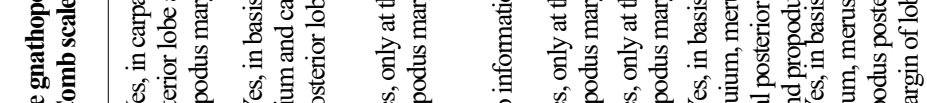

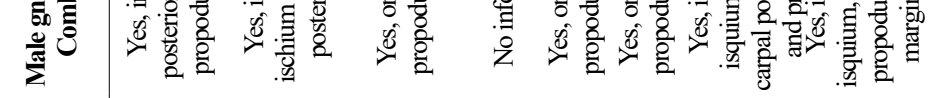

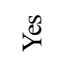

z

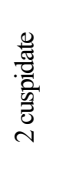

爱

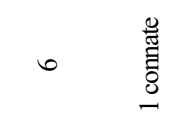

के

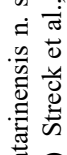

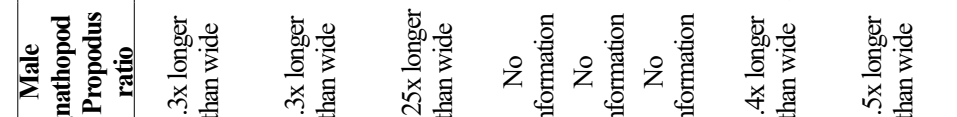

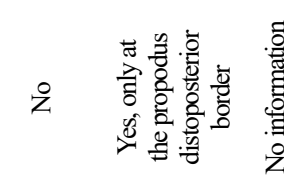

西

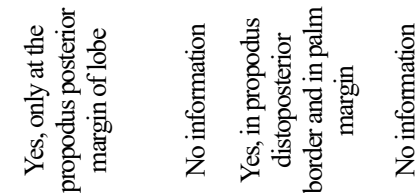

章

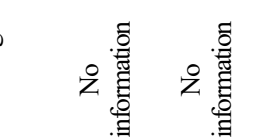

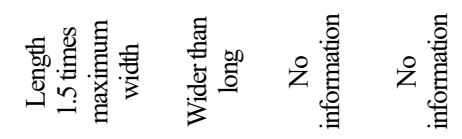

造

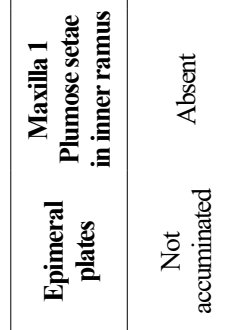

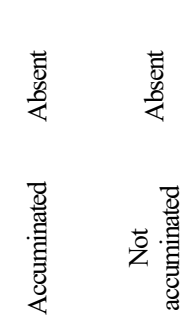

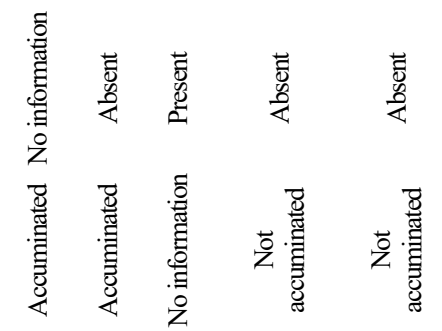

离

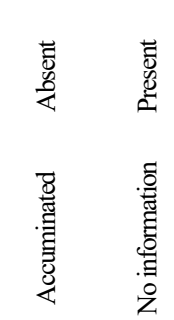

莺

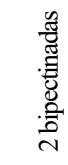

㓤耪

定

웡

$\|1\|$

II

1

11

111

m

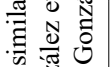

III

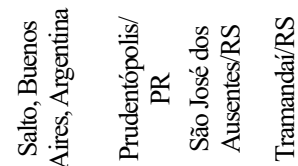

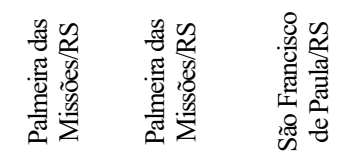

II

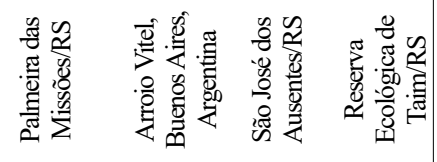

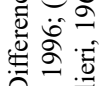

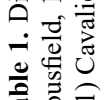

1

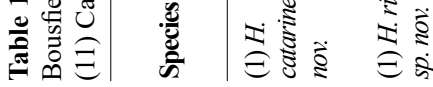

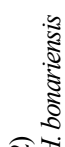

$11 ! 1 !$

章

I

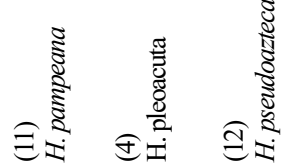




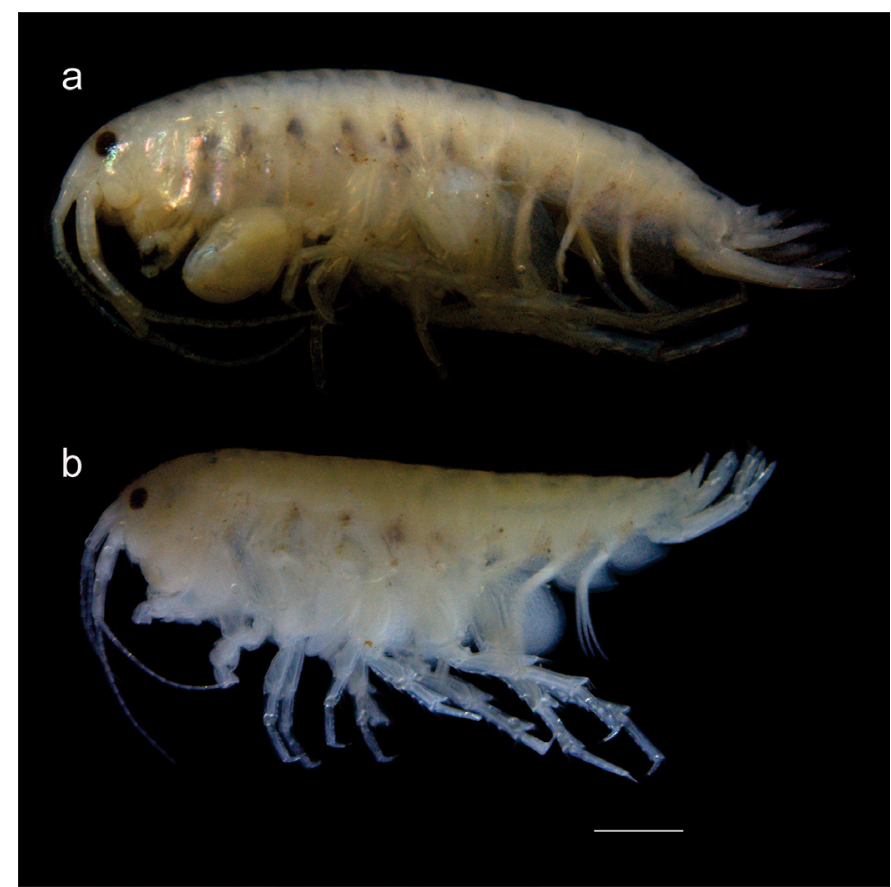

Figure 8. Hyalella rioantensis n. sp., municipality of Rio das Antas, Santa

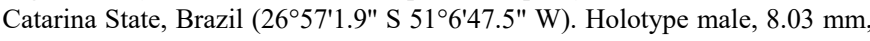
MZUSP 39531 (a); paratype, female, 6.77 mm, MZUSP 39532 (b). Scale bars $=1000 \mu \mathrm{m}$.

apical and medial pappose setae, without comb-scales; palp longer than inner and outer plate, with four articles; article $11.3 \mathrm{x}$ longer than wide, outer margin with one simple seta; article $21.5 \mathrm{x}$ longer than wide, inner margin with four pappose setae and several simple setae; article $31.7 x$ longer than wide, outer and inner margins with simple and pappose setae, without comb-scales; article 4 unguiform, $0.8 \mathrm{x}$ shorter than third article, $3.4 \mathrm{x}$ longer than wide, one distal long pappose setae, with comb-scales, and distal nail absent.

Gnathopod 1 (Figure 10a1, a2) subchelate; coxal plate 1.7x longer than wide, with simple setae on the margin; basis and ischium with dorsal and apical pappose setae and comb-scales; merus with pappose setae on distal margin, with comb-scales; carpus $1.5 x$ longer than wide, $1.2 \mathrm{x}$ longer than the propodus, with lateral distal lobe produced, with three simple setae on inner margin, pappose setae and comb-scales on posterior lobe; propodus length 1.6x maximum width (quadrangular), hammer-shaped, with pappose setae on disto-anterior margin, with comb-scales, inner margin with simple setae on the disto-posterior margin, with comb-scales; palm slope transverse, with many simple setae, margin slightly concave, posterior distal corner with one long and strong cuspidate seta with accessory seta; dactylus claw-like, with comb-scale, with one plumose seta dorsally.

Gnathopod 2 (Figure 10b1, b2, b3) subchelate; coxal plate 1.8x longer than wide, with simple setae on the margin; basis and ischium with simple setae, some with accessory seta, and comb-scales on posterior margin; merus with few simple setae on posterior margin, some with accessory seta, without comb-scales; carpus $2 \mathrm{x}$ wider than long, posterior lobe produced between merus and propodus, forming a scoop-like structure, margin with pappose setae; propodus ovate, $1.3 \mathrm{x}$ longer than wide; palm equal in size to posterior margin of propodus, slope transverse, margin with several simple setae, posterior distal corner

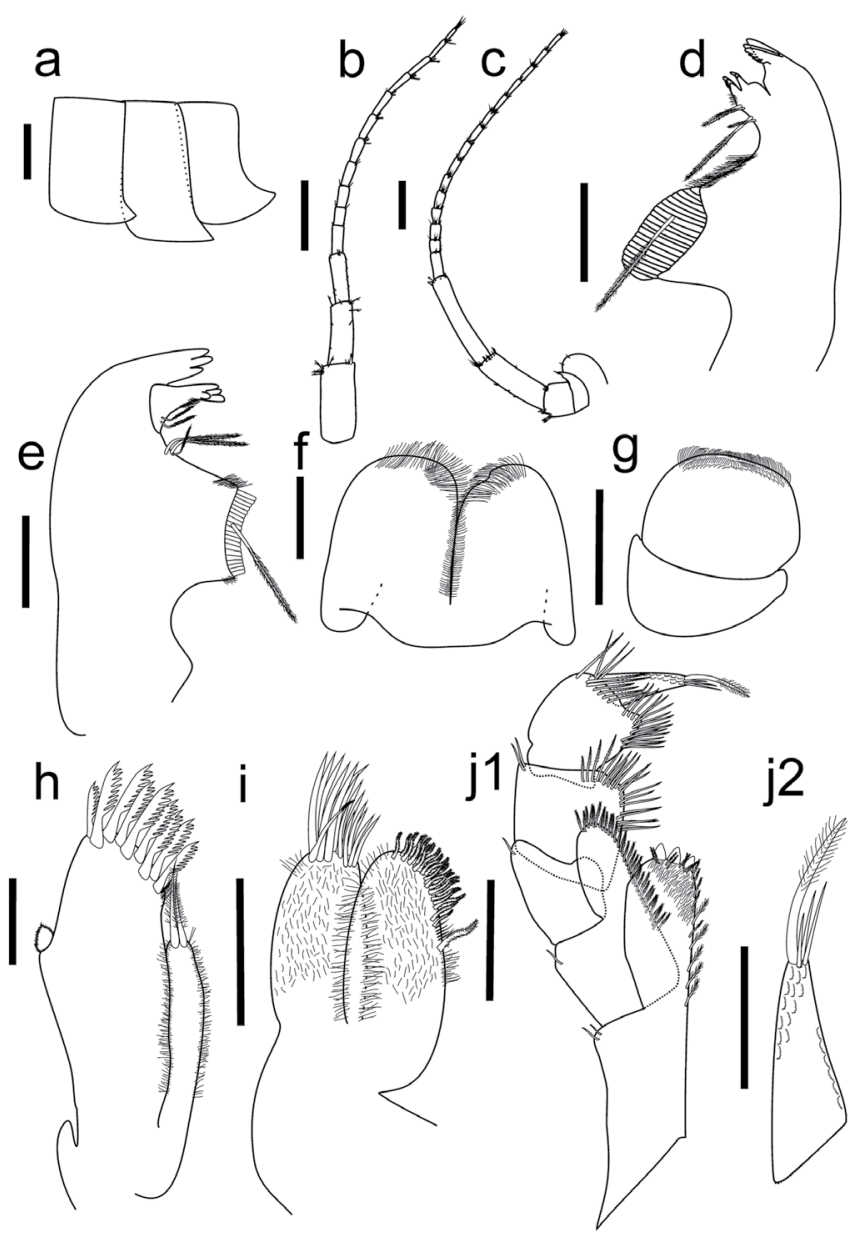

Figure 9. Hyalella rioantensis n. sp., municipality of Rio das Antas, Santa Catarina State, Brazil (26 $\left.57^{\prime} 1.9^{\prime \prime} \mathrm{S} 51^{\circ} 6^{\prime} 47.5^{\prime \prime} \mathrm{W}\right)$. Paratype, male, $7.96 \mathrm{~mm}$. Epimeral plates accuminated (a). Antenna 1 (b). Antenna 2 (c). Right mandible (d). Left mandible (e). Lower lip (f). Upper lip (g). Maxilla 1 (h). Maxilla 2 (i). Maxilliped (j1). Detail of the maxilliped (j2). Scale bars: $a=1000 \mu \mathrm{m} ; \mathrm{b}$ and $\mathrm{c}=500 \mu \mathrm{m} ; \mathrm{d}$ and $\mathrm{e}=100 \mu \mathrm{m} ; \mathrm{f}, \mathrm{i}$ and $\mathrm{h}=125 \mu \mathrm{m} ; \mathrm{g}=200 \mu \mathrm{m} ; \mathrm{j} 1=250 \mu \mathrm{m}$; $\mathrm{j} 2=125 \mu \mathrm{m}$.

with comb-scales and with a deep cup for the dactylus; dactylus clawlike, congruent with palm, plumose seta dorsally, comb-scales absent.

Pereopods 3 to 7 (Figure 11a-e) simple. Pereopods 3 and 4: merus and carpus posterior margin with several pappose and simple setae with accessory seta; propodus posterior margin of pereopod 3 and 4 with pappose setae, simple and cuspidate setae with accessory seta; dactylus $3.3 \mathrm{x}$ and $4.4 \mathrm{x}$ shorter than propodus, respectively, with a plumose seta dorsally. Pereopods 5 to 7 : merus, carpus and propodus posterior margin with several cuspidate setae some of them with accessory seta, dactylus $3.3 \mathrm{x}, 4.9 \mathrm{x}$ and $5.5 \mathrm{x}$ shorter than propodus, respectively, with a plumose seta dorsally, except on pereopod 7. Pereopods 4 and 5 similar sizes; pereopod 5 smaller than pereopod 3; pereopod 7 longer than pereopod 6 .

Pleopods (Figure 12a) peduncle $2.7 \mathrm{x}$ longer than wide, $0.6 \mathrm{x}$ the mean size of rami, with two coupling spines; both rami with several plumose setae.

Uropod 1 (Figure 12b) 1.4x longer than uropod 2; peduncle slightly longer than outer ramus and subequal to inner ramus, with four to six cuspidate setae with accessory seta; inner ramus slightly longer than outer ramus, 5.6x longer than wide, with three cuspidate setae on the 


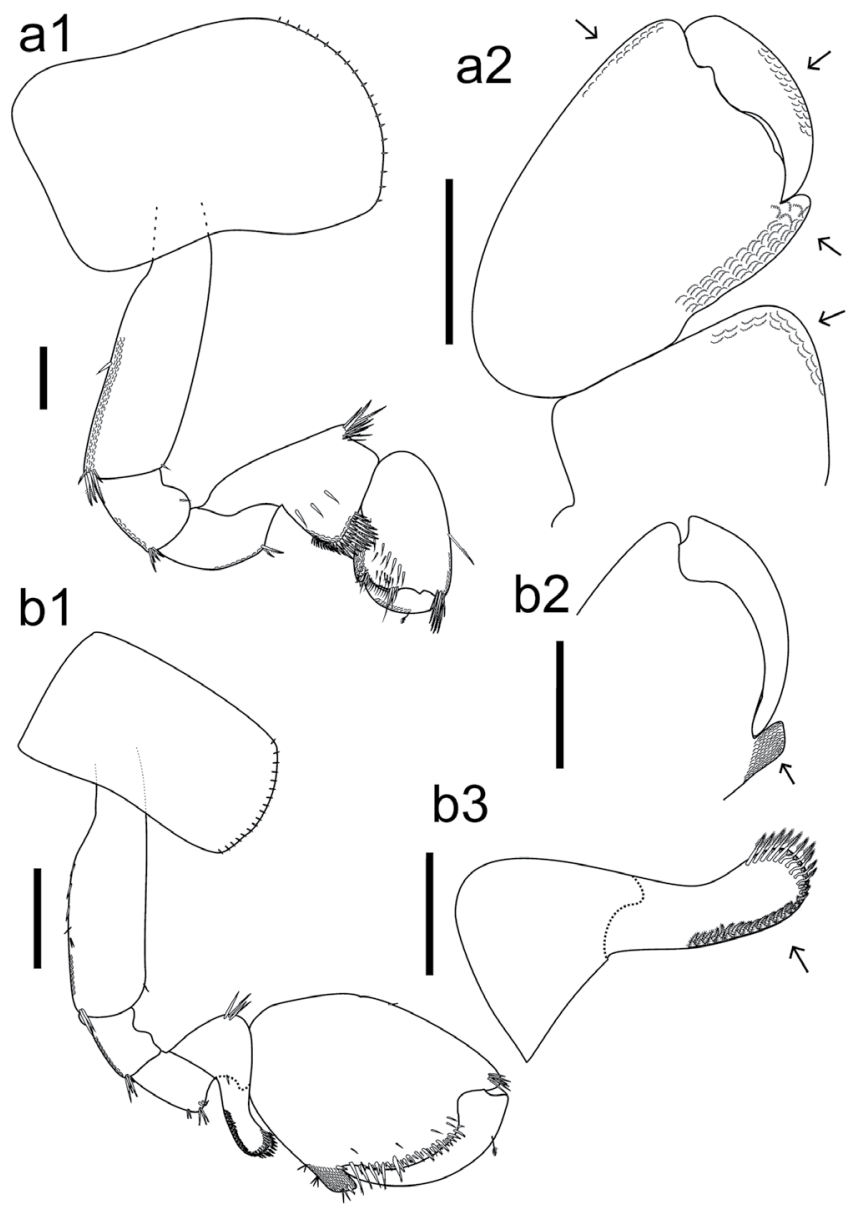

Figure 10. Hyalella rioantensis n. sp., municipality of Rio das Antas, Santa Catarina State, Brazil (26 $57^{\prime} 1.9^{\prime \prime}$ S 51 $\left.{ }^{\circ} 6^{\prime} 47.5^{\prime \prime} \mathrm{W}\right)$. Paratype, male, $7.96 \mathrm{~mm}$. Gnathopod 1 (a1). Detail of the carpus, propodus and dactylus (a2). Gnathopod 2 (b1). Detail of the propodus and dactylus (b2). Detail of the carpus (b3). Scale bars $=200 \mu \mathrm{m}$.

margin and five cuspidate setae apically, male with a curved seta; outer ramus $5.5 \mathrm{x}$ longer than wide, with four cuspidate setae on the margin, four cuspidate setae apically.

Uropod 2 (Figure 12c) 1.9x longer than uropod 3, peduncle subequal to rami, with three or four cuspidate setae with accessory seta; inner ramus $1.2 \mathrm{x}$ longer than outer ramus, $4.3 \mathrm{x}$ longer than wide, outer ramus 4.1x longer than wide, with four cuspidate setae with accessory seta on the margin, four cuspidate setae with accessory seta apically, one of them much smaller than the others.

Uropod 3 (Figure 12d) 0.7x shorter than peduncle of uropod 1 and slightly longer than peduncle of uropod 2; peduncle globose, $1.5 \mathrm{x}$ longer than wide, without or with up to three basal simple setae, six distal cuspidate setae with accessory seta; inner ramus absent; outer ramus uniarticulate; ramus $1.3 \mathrm{x}$ longer than peduncle, $4.4 \mathrm{x}$ longer than wide, with four cuspidate setae.

Telson (Figure 12e) entire, slightly (1.1x) longer than wide, apically rounded, with four apical cuspidate setae with accessory seta, simetrically, without setae laterally. Variations: three to five apical cuspidate setae with accessory seta. 2 to 7 .

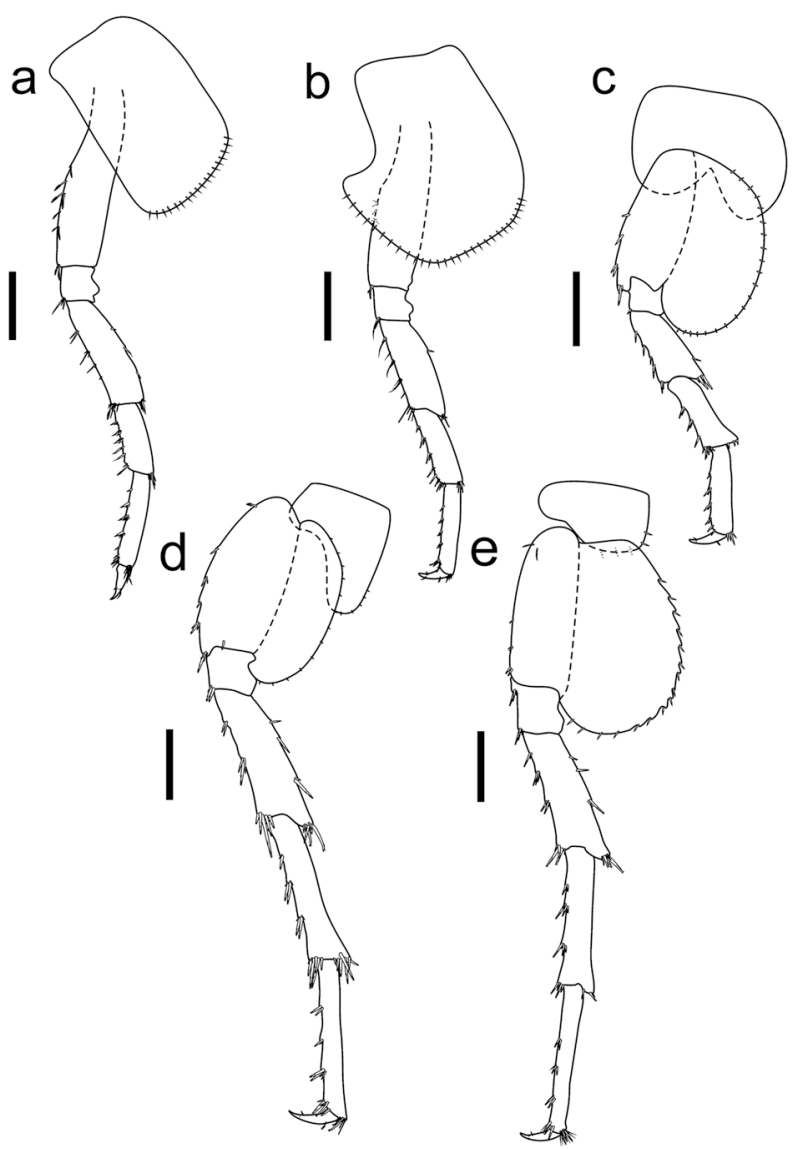

Figure 11. Hyalella rioantensis n. sp., municipality of Rio das Antas, Santa

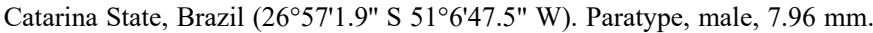
Pereopod 3 (a). Pereopod 4 (b). Pereopod 5 (c). Pereopod 6 (d). Pereopod 7 (e). Scale bars $=500 \mu \mathrm{m}$.

Female (Figure 8b). Mean body length: $6.24 \pm 1.12 \mathrm{~mm}(N=10)$, minimum body length $=5.98 \mathrm{~mm}$, maximum body length $=7.86 \mathrm{~mm}$; mean head length: $0.80 \pm 0.17 \mathrm{~mm}(N=10)$, minimum head length $=0.74 \mathrm{~mm}$, maximum head length $=0.88 \mathrm{~mm}$. Gnathopod 1 (Figure 13a1, a2) similar to male gnathopod 1; carpus $1.5 \mathrm{x}$ longer than wide, with comb-scales; posterior lobe produced and forming a scoop-like structure, with pectinate margin, with several pappose setae; propodus 1.6x longer than wide, hammer-shaped, with comb-scales, palm shorter than posterior margin of propodus, inner margin with few simple setae, palm slope transverse, dactylus claw-like. Gnathopod 2 (Figure 13b1, b2) similar in shape and size to gnathopod 1; propodus 1.9x longer than wide, with comb-scales, inner margin with few simple setae, palm slope transverse with few simple setae. Telson (Figure 13c) 1.2x longer than wide, similar in shape to male, with two to four cuspidate setae with accessory seta.

Taxonomical remarks. Among all species that are described for Brazil, Hyalella rioantensis n. sp. differs from $H$. pleoacuta, H. kaingang and $H$. pseudoazteca by the absence of flanges. The new species differs from $H$. bonariensis, $H$. gauchensis and $H$. georginae by epimeral plates accuminated. The absence of plumose setae in maxilla 2 distinguishes $H$. rioantensis n. sp. from $H$. Catarinensis n. sp., $H$. curvispina, $H$. 


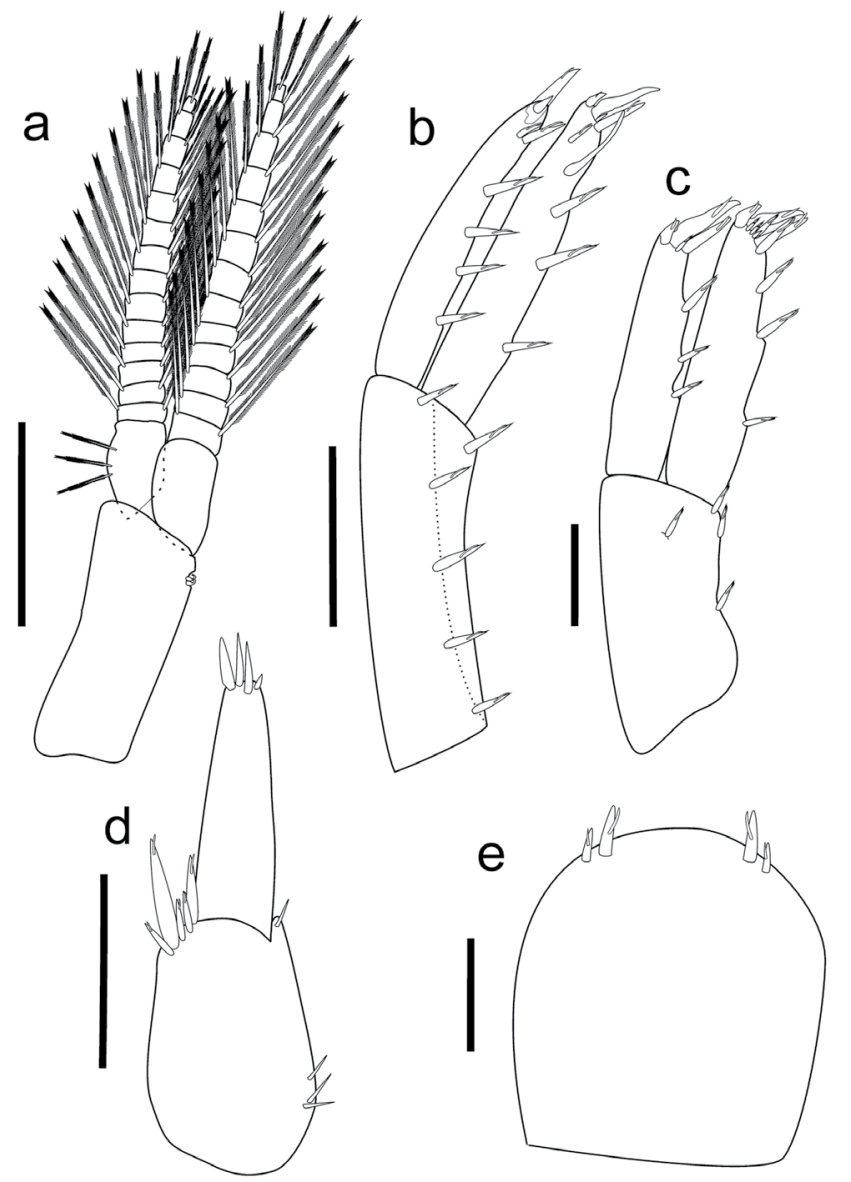

Figure 12. Hyalella rioantensis n. sp., municipality of Rio das Antas, Santa

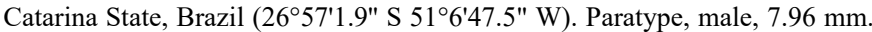
Pleopod (a). Uropod 1 (b). Uropod 2 (c). Uropod 3 (d). Telson (e). Scale bars: $\mathrm{a}=500 \mu \mathrm{m} ; \mathrm{b}=400 \mu \mathrm{m} ; \mathrm{c}$ and $\mathrm{d}=200 \mu \mathrm{m} ; \mathrm{e}=125 \mu \mathrm{m}$.

montenegrinae, $H$. pampeana and $H$. brasiliensis. Additionally, $H$. rioantensis $\mathrm{n}$. sp. also differs from $H$. montenegrinae, $H$. castroi and H. pleoacuta by the absence of plumose setae in the maxilliped. The two new species presented in this work also differ in the distal nail of the maxilliped, which is absent in H. rioantensis $\mathrm{n}$. sp., and it is different from $H$. castroi, $H$. curvispina, $H$. kaingang, $H$. misionensis, $H$. pleoacuta, $H$. pseudoazteca and H. palmeirensis's maxilliped. The palm equal in size to the posterior margin of propodus in gnathopod 2 discerns $H$. rioantensis n. sp. from $H$. georginae, $H$. gauchensis, $H$. pleoacuta . It is possible to differentiate $H$. rioantensis n. sp. from $H$. pampeana, $H$. montenegrinae, $H$. bonariensis, $H$. kaingang, $H$. georginae, $H$. gauchensis and $H$. palmeirensis by the absence of lateral setae on telson. The characteristic that distinguishes $H$. rioantensis $\mathrm{n}$. sp. from H. pseudoazteca and H. misionensis is the presence of curved setae on inner ramus of male uropod 1. All similarities and differences between H. rioantensis $\mathrm{n} . \mathrm{sp}$. and others species can be checked on Table 1 .

Etymology. The species epithet "rioantensis" is in reference to the municipality of Rio das Antas.

Habitat and Ecological Conservation. Epigean. Lake in private property, with preserved native vegetation; without pollution or apparent contamination.

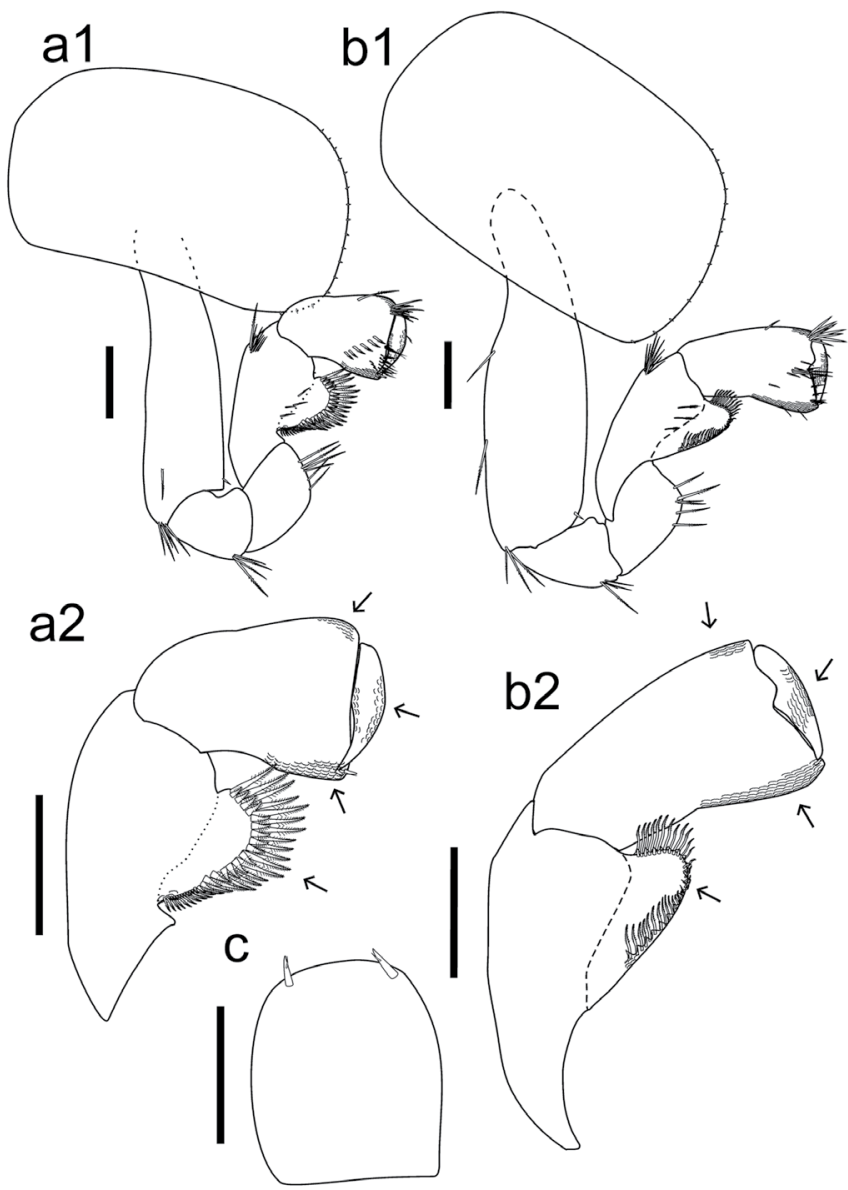

Figure 13. Hyalella rioantensis n. sp., municipality of Rio das Antas, Santa Catarina State, Brazil (26 $57^{\prime} 1.9^{\prime \prime}$ S 51 ${ }^{\circ} 6^{\prime} 47.5^{\prime \prime}$ W). Paratype, female, $6.77 \mathrm{~mm}$. Gnathopod 1 (a1). Detail of the carpus, propodus and dactylus (a2). Gnathopod 2 (b1). Detail of the carpus, propodus and dactylus (b2). Telson (c). Scale bars $=200 \mu \mathrm{m}$.

\section{Discussion}

The genus Hyalella is exclusive to American freshwater systems and has a great geographic distribution within the continent. The greatest diversity of the genus so far can be found in colder waters (Rodrigues et al. 2014), such as the Titicaca lake (González \& Watling 2003; Adamowicz et al. 2018), temperate lakes along northern United States (March 1978), and even the South region of Brazil. Moreover, Santa Catarina state comprises 18 main subwatersheds, seven of them belonging to the Parana-Uruguay basin (Santa Catarina 2016), the one that occurs both $H$. catarinensis $\mathrm{n}$. sp. and $H$. rioantensis $\mathrm{n}$. $\mathrm{sp}$. Considering this, we can assume that the lack of species recorded for the state of Santa Catarina is mainly due to insufficient research and / or collection, and not due to the scarce diversity of amphipods for the state.

Among all the characteristics that Hyalella catarinensis n. sp.. shares with Hyalella rioantensis $\mathrm{n}$. $\mathrm{sp}$. as highlighted are the absence of flanges; coxa 1 similar to 2 and 3; left mandible with lacinia mobilis with four teeth, a row of five papposerrate setae; right mandible with four papposerrate setae; maxilla 1 with inner plate smaller than outer plate, with two papposerrate setae; inner plate of maxilla 2 with 
papposerrate setae, outer plate with simple setae, plates covered with setules; maxilliped inner plate longer than wide, without comb scales, outer plate with setae, article 1 of palp longer than wide, outer margin with a one seta, article 3 of palp longer than wide, inner and outer margin with the simple and pappose setae; gnathopod 1 coxal plate wider than long, with simple setae on the margin, carpus longer than wide, palm of the propodus with many simple setae, distal posterior margin with cuspidate and accessory setae, dactylus with comb-scales; coxal plate in gnathopod $21.8 x$ longer than wide, with simple setae on margin, merus with simple setae, propodus $1.3 x$ longer than wide, with dorsal plumose seta, without comb-scales; inner ramus of uropod 1 with curved setae; telson with apex rounded and without lateral arrows.

The main characteristics that differentiate Hyalella catarinensis $\mathrm{n}$. sp. from $H$. rioantensis $\mathrm{n}$. sp. are eyes oval and lateral pappose setae in article 4 of antenna 2, present only in $H$. catarinensis n. sp.; pappose setae on the inner plate of the maxilla 2, present only in $H$. catarinensis n. sp.; pappose setae on the outer plate of maxilla 2, present only in $H$. rioantensis $\mathrm{n}$. sp.; distal nail absent in $H$. rioantensis $\mathrm{n}$. sp.; absence of comb scales on maxilliped in $H$. catarinensis n. sp.; presence of comb scales on merus and carpus, dactylus with plumose setae on gnathopod 1 in $H$. rioantensis n. sp.; presence of comb scales on carpus of gnathopod 2 in $H$. catarinensis $\mathrm{n}$. sp. and on palm of propodus in H. rioantensis n. sp.; both species differ in number of setae and ramus/peduncle ratio in uropod 1 and uropod 2; telson with three apical setae and accessory seta in $H$. catarinensis n. sp., with only three apical without accessory setae in $H$. rioantensis $\mathrm{n}$. sp.

In this manuscript we update the taxonomic knowledge for the genus and expand its known area of occurrence. In this sense, the diversity of Hyalella increases to 16 species only in the southern region of Brazil. We expect that this work will contribute to future taxonomic research, besides contributing to the conservation of freshwater habitats, essential for the occurrence of these species and many other species.

\section{Acknowledgements}

The authors are grateful to Universidade Federal de Lavras (UFLA) and Centro de Biologia Subterranea (CEBS-UFLA) for logistic support. This study was financed in part by Coordenação de Aperfeiçoamento de Pessoal de Nível Superior - Brazil (CAPES) - Finance Code 001 (LRP); we also thank the anonymous reviewers for their insights, and the following agencies for their financial support: (AAPB) Conselho Nacional de Desenvolvimento Científico e Tecnológico (CNPq) process number 477554/2011-2; and (GOR) PIBIC/UFLA scholarship.

\section{Author's contribuition}

Giovanna O Reis: Substantial contribution in the concept and design of the study; contribution to data collection, analysis and interpretation; contribution to manuscript preparation, critical revision and adding intellectual content.

Ludmila R. Penoni: Substantial contribution in the concept and design of the study; contribution to data collection, analysis and interpretation; contribution to manuscript preparation, critical revision and adding intellectual content.

Alessandra A.P. Bueno: Contribution to manuscript preparation, critical revision and adding intellectual content.

\section{Conflicts of interest}

The authors declare that they have no conflict of interest related to the publication of this manuscript.

\section{References}

ADAMOWICZ, S.J., CRISTINA MARINONE, M., MENU MARQUE, S., MARTIN, J.W., ALLEN, D.C., PYLE, M.N., DE LOS RÍOSESCALANTE, P.R., SOBEL, C.N., IBAÑEZ, C., PINTO, J. \& WITT, J.D.S. 2018. The Hyalella (Crustacea: Amphipoda) species cloud of the ancient Lake Titicaca originated from multiple colonizations. Mol. Phylogenet. evol. 125: 232-242. https://doi. org/10.1016/j.ympev.201803.004

BASTOS-PEREIRA, R., OLIVEIRA, M.P.A. \& FERREIRA, R.L. 2018. Anophitalmic and epigean? Description of an intringuing new species of Hyalella (Amphipoda, Hyalellidae) from Brazil. Zootaxa. 4407(2): 254-266. https://doi.org.10.11646/zootaxa.4407.2.6

BOND-BUCKUP, G. \& ARAUJO, P.B. 1998. Hyalella montenegrinae sp. n., um amphipoda de águas continentais do Sul do Brasil (Crustacea, Peracarida, Hyalellidae). Nauplius. 6: 53-59.

BOUSFIELD, E.L. 1996. A contribution to the reclassification of Neotropical freshwater hyalellid amphipods (Crustacea: Gammaridae: Talitroidea). Bolletino del Museo Civico di Storia Naturale de Verona. 20: 175-244.

BUENO, A.A.P., ARAUJO, P.B., CARDOSO, G.M. \& GOMES, K.M. 2013. Two new species of Hyalella (Amphipoda, Dogielinotidae) from Brazil. Crustaceana. 86(7-8): 802-819.

BUENO, A.A.P., OLIVEIRA, K.M. \& WELLBORN, G. 2019. A new species of Hyalella Smith, 1874 (Crustacea: Amphipoda: Hyalellidae) from Oklahoma, USA. Zootaxa. 4700(2): 259-269. https://doi.org/10.11646/zootaxa.4700.2.5

BUENO, A.A.P., RODRIGUES, S.G. \& ARAUJO, P.B. 2014. O estado da arte do gênero Hyalella Smith, 1874 (Crustacea, Amphipoda, Senticaudata, Hyalellidae) no Brasil. In: CARMINO HAYASHI. (Org.). Tópicos de atualização em Ciências Aquáticas. 1 ed. Uberaba: UFMT, 1: 57-88.

CARDOSO, G.M., ARAUJO, P.B., BUENO, A.A.P. \& FERREIRA, R.L. 2014. Two new subterranean species of Hyalella Smith, 1874 (Crustacea: Amphipoda: Hyalellidae) from Brazil. Zootaxa. 3814(3): 353-368. https://dx.doi.org//10.11646/zootaxa.3814.3.3

CAVALIERI, F. 1968. Hyalella pampeana sp. n., una nueva especie de afípodo de agua dulce (Gammarida: Hyalellidae). Neotropica. 14(45): 107-117.

COLLA, M. F. \& CÉSAR, I.I. 2015. A new species of Hyalella (Crustacea, Amphipoda, Dogielinotidae) from the Atlantic Forest of Misiones, Argentina. Zookeys. 481: 25-38. https://doi:10.3897/ zookeys.481.9037

GONZÁLEZ, E.R., BOND-BUCKUP, G. \& ARAUJO, P.B. 2006. Two new species of Hyalella from Southern Brazil (Amphipoda: Hyalellidae) with a taxonomic key. J. Crustacean Biol. 26(3): 355-365. https://doi.org/10.1651/C-2599.1

GONZÁLEZ, E.R. \& WATLING, L. 2003a. A new species of Hyalella from Brazil (Crustacea: Amphipoda: Hyalellidae), with redescriptions of three other species in the genus. J. Nat. Hist. 37(17): 2045-2076. https://doi:10.1080/00222930210133237

GROSSO, L.E. \& PERALTA, M. 1999. Anfípodos de agua dulce sudamericanos: revisión del género Hyalella Smith. I. Acta Zoologica Lilloana. 45(1): 79-98. 
MARCH, B.D. 1978. The effects of constant and variable temperatures on the size, growth, and reproduction of the freshwater amphipod Hyalella azteca (Saussure). Can. J. Zool. 56(8): 1801-1806.

PERALTA, M.A. \& ISA MIRANDA, Á.V. 2019. A new species of Hyalella (Crustacea, Amphipoda, Hyalellidae) from the Puna biogeographic province in Argentina. Zookeys. 865: 87-102. https:// doi:10.3897/zookeys.865.32878

RODRIGUES, S.G., BUENO, A.A.P. \& FERREIRA, R.L. 2012. The first hypothelminorheic Crustacea (Amphipoda, Dogielinotidae, Hyalella) from South America. ZooKeys. 236: 65-80. https://doi: 10.3897/zookeys. 236.3930

RODRIGUES, S.G., BUENO, A.A.P. \& FERREIRA, R.L. 2014. A new troglobiotic species of Hyalella (Crustacea, Amphipoda, Hyalellidae) with a taxonomic key for the Brazilian species. Zootaxa. 3815(2): 200-214. https://dx.doi.org/10.11646/zootaxa.3815.2.2

RODRIGUES, S.G., SENNA, A.R., QUADRA, A., BUENO, A.A.P. 2017. A new species of Hyalella (Crustacea: Amphipoda: Hyallelidae) from Itatiaia National Park, Brazil: an epigean freshwater amphipod with troglobiotic traits at 2,220 meters of altitude. Zootaxa. 4344(1): 147-159. https://doi.org/10.11646/ zootaxa.4344.1.6

SANTA CATARINA. 2016. Hidrografia. In Atlas geográfico de Santa Catarina: diversidade da natureza - fascículo 2 (I.O. Rocha, org.). Secretaria de Estado e Planejamento, Diretoria de Estatística e Cartografia, Florianópolis, p.114-140.

SANTOS, A.L.F., ARAUJO, P.B. \& BOND-BUCKUP, G. 2008. New species and new reports of Hyalella (Crustacea, Amphipoda, Dogielinotidae) from Argentina. Zootaxa. 1760: 24-36. https://doi: 10.11646/Zootaxa.1760.1.2
SMITH, S. 1874. The Crustacean of the fresh Waters of the United States - Synopsis of the higher fresh-water Crustacea of the Northern United States. Report of the Commissioner of Fishand Fisheries. 2: 637-665.

SHOEMAKER, C.R. 1942. A new species of Amphipoda from Uruguay and Brazil. Journal of the Washington Academy of Sciences. 32(3).

STRECK, M.T., CARDOSO, G.M., RODRIGUES, S.G., GRAICHEN, D.A.S \& CASTIGLIONI, D.S. 2017. Two new species of Hyalella (Crustacea, Amphipoda, Hyalellidae) from state of Rio Grande do Sul, Southern Brazil. Zootaxa. 4337(2): 263-278. https://doi. org/10.11646/zootaxa.4337.2.5

STRECK-MARX, M. \& CASTIGLIONI, D.S. 2019. A new species of freshwater amphipod (Crustacea, Amphipoda, Hyalellidae) from state of Rio Grande do Sul, Southern Brazil. Biota Neotropica. 20(1): e20190802, 2020. https://dx.doi.org/10.1590/1676-0611BN-2019-0802 (last access on 25/03/2020)

ZIMMER, A., ARAUJO, P.B. \& BOND-BUCKUP, G. 2009. Diversity and arrangement of the cuticular structures of Hyalella (Crustacea: Amphipoda: Dogielinotidae) and their use in taxonomy. Zoologia. 26(1): 127-142. https://dx.doi.org/10.1590/s198446702009000100019
Received: $28 / 08 / 2019$

Revised: $27 / 03 / 2020$

Accepted: 03/04/2020

Published online: 18/05/2020 